\title{
ON THE ROMAN VILLAS ON THE SOUTH OF PROVINCE OF DALMATIA (Several examples from the area of East Herzegovina) ${ }^{2}$
}

ABSTRACT. This paper presents the data regarding Roman villas in the valley of the Trebišnjica River in East Herzegovina (south of province of Dalmatia). The bases for successful research of Roman villas in this region are original written records and material remnants on the terrain (epigraphic monuments, remnants of buildings, settlements, and roads, fragments of bricks, roof tiles, processed stone, Roman ceramics, glass, vessels and amphorae, fragments of frescoes, mosaics, torcularium, money etc.). Archeological discoveries point out that continuity of populating this region could be traced from prehistorical period until modern age. The area which will be researched in this paper is located near the Trebišnjica River. It is the area with very convenient climate conditions for the development of agriculture and livestock farming. It caused this region to be populous in ancient time. In this paper we will present discoveries from Roman time from the locations of Crkvina-Prežani (villa urbana), Dračeva strana (villa rustica),

\section{gligorijas@yahoo.com}

2 The paper presents the results of research conducted under the Project No. III 47023 Kosovo and Metohija between national identity and European integration, which is funded by the Ministry of Education, Science and Technological Development of the Republic of Serbia.

This paper was submitted on August $21^{\text {st }}, 2016$ and accepted for publication at the meeting of the Editorial Board held on September 29, 2016. 
Potkućnice (villa rustica) and villa rustica very close to bank of the Trebišnjica River (Panik) southern from Bileća, Mirina and Lijeska villa rustica (Bihovo) near Trebinje, as well as the location of Tanoge in Ljubomir (villa rustica) northern from Trebinje.

KeY WORDS: Roman villas, Panik, Crkvina, Dračeva strana, Potkućnice, Mirine, Lijeska, Bihovo, Tanoge, Ljubomir, East Herzegovina, Dalmatia.

Interest for archaeological remnants in East Herzegovina appeared very early. The research of these remnants started from individual excavating and gathering and was carried on as organized and systematic research of certain areas. At the beginning, individual result of excavating and archaeological founds and later on organized research of certain localities contributed to the better understanding of the history of this region. Found and elaborated materials were one of the bases for research of the oldest and older historical periods. Buried, sunken, used for later building, stored in different collections, overage and time-worn archaeological remains and monuments were valuable souses. To be more precise, the beginning of organized archaeological research of remains form the Roman period in Bosnia and Herzegovina started in the second half of the XIX century. The first papers related to organized research of Roman houses (villa) in East Herzegovina appeared in 1892 and 1893 (Truhelka, 1892, p. 354-356; Fiala, 1893, pp. 511-532).

All these houses (villa) were similar in terms that they all had several objects which were residential and economic premises as well as baths. In time, they became different and separate objects and there were villas with dominant features, so new different types and categories of villas were formed. Villa rustica was defined as agricultural estate with tight connection between productive and residential part (Percival, 1976, p. 13-15; Thomas, 1980, p. 276; Mielsch, 1987, p. 7; Smith, 2006, p. 6-9; Busuladžić, 2011, p. 23). Villa suburbana was a residential house of a socially wealthy city class in the city neighborhood (Mlakar, 1962, p. 28; Busuladžić, 2011, p. 25-26), while the term ville urbane denoted a luxurious residential family house in a city (Mielsch, 1987, p. 7; Busuladžić, 2011, p. 26).

In the valley of the Trebišnjica River in East Herzegovina organized researches were carried on in Panik near Bileća: four Roman houses (vill?) and one villa per locations: Mirina in Bihovo near Trebinje, Lijeska near Mirina and in Ljubomir above Trebinje (Čremošnik, 1976, p. 41-132; p, 1976, p. 289-293; Busuladžić, 2002, 
p. 191-196; Busuladžić, 2011, p. 31, 154-156). There were numerous archaeological founds proving that the valley of the Trebišnjica River was a settled place during Roman time. This area became interesting for researchers at the end of XIX and beginning of XX century when road Ad Zizio-Asamo-Epidauro-Scodra was researched. Researches in the valley of the Trebišnjica River proved reasonable suggestion about existence of Roman settlements in this region (ILJug 106; ILJug 615b; ILJug 647; CIL III 14620; Tab. Peut. 467, 468, 469, 470; It. Ant. 337, 338, 339; Miliaria Imperii Romani, 20012, 224, 234 ; Sergejevski, 1962a, p. 73-105; Sergejevski, 1962?, p. 111-113; Bojanovski, 1962, p. 11-13; Sergejevski, 1964, p. 93-95; Alföldy, 1969, pp. 135, 150, 267, 331-332, 305; Bojanovski, 1973, pp. 137-187; AE 1977, 611; Bojanovski, 1977, pp. 67-98; Škrivanić, 1975: pp. 51-52; Bojanovski, 1983, pp. 7-36; Bojanovski, 1988, pp. 76-87; Samardžić, 2015, pp. 201-249, 261-263).

Furthermore, there were discoveries of more villas without systematic research in the area near the Trebišnjica River: in the place Ušće, on the location Lijeska in the village of Bihovo, as well as in Domaševo, Ukšići, Vrpolje, Cibrijan, Mosk, Skrobotno, Miruše, Police, Aleksina Međa, Čičevo, Poljice, Dubočani, Fatnica, Hum, Perović (earlier Arslanagić) Bridge on the territory of Trebinje municipality (AL BiH III 1988, p. 184; Bojanovski, 1964, p. 197; Čremošnik, 1976, pp. 41-132; Paškvalin, 1976, pp. 289-293; Busuladžić, 2002, pp. 191-196; Busuladžić, 2011, pp. 31, 154-156; Samardžić, 2015, pp. 201-249, 261-263). Also, there was one villa in the place Kazanci, eastern from Gacko (Bojanovski, 1976, p. 32).

Systematic archaeological researches on the location of Panika near Bileća started in the mid XX century. Its beginning was connected with the building of the hydro power plants in the basin of the Trebišnjica River, because it was planned that this region should be sunken. Researchers from the National Museum of Bosnia and Herzegovina visited the location of Panika near Bileća in 1957. It was necessary to mark archaeological locations where systematic researchers should be carried out. After that, in 1959 they organized probationary excavation and a detailed examination of the terrain organized by Trebinje Heritage Museum. Ljubinka Kojić (Museum director) and Ilija Pušić (a curator from Herceg Novi) participated in the research. After examination of the terrain, they stated that a Roman settlement was covering the area of about 20 hectare, from hamlet Parežani to Trebišnjica on one side, and from fields called Potkućnice to hamlet Prlo on the other 
side. Smaller probationary excavations on the same location were carried on in 1960 by the same group of researchers. They researched remains of two Roman buildings on Dračeva strana, but the research results have not been published. Detailed systematic research started in 1967 on the location of Panika in cooperation with the National Museum of Bosnia and Herzegovina, Trebinje National Museum and Stanford University (USA) whose representative was Professor Mario Del Chiaro (Čremošnik, 1960-1961, pp. 172-182; Kojić, 1960-1961, pp. 185-187; Čremošnik, 1976, pp. 41-44; Samardžić, 2015, pp. 199-249).

Systematic researches on the location of Panik, as we said, started in 1967 in Crkvina, where numerous building remains were discovered (picture No. 1). A great luxurious building (object I) type 'U'-villa was discovered on this location. It was located near Trebišnjica and spread from the river, through terrain terrace which slightly ascended all to the Prla and Roman road and the tombs near it (AL BiH III 1988, p. 171; Čremošnik, 1960-61, pp. 174-182; Čremošnik, 1976, pp. 41-58; Busuladžić, 2011, pp. 154-155; Samardžić, 2015, pp. 199-249). The building was very well preserved. It consisted of two wings which were connected to porches and thus they formed a great square space. Porches and back premises towards Trebišnjica were not preserved. South-west wing of ' $U$ '-villa was connected to several premises and their existence could be seen thanks to the walls remains. Near to the east complex of ' $U$ ' villa premises, to north, was the other object (II) with a group of larger premises with hypocaust. Further, towards north-west from these premises there was the third object (III). Only basement of this object was preserved and later on a church was built on it. Although all the walls of the object towards north and west were not preserved, it could be seen they existed (AL BiH III 1988, p. 171; Čremošnik, 1976, pp. 44-58; Busuladžić, 2011, pp. 154-155; Samardžić, 2015, pp. 199-249). The second and third object (II, III) with group of premises encircled another great open space. From objects which surrounded this open space, only remaining parts of a longer wall from north-west side, near graveyard Crkvine, was preserved (AL BiH III 1988, p. 171; Čremošnik, 1960-61, pp. 174-182; Čremošnik, 1976, pp. 41-58; Busuladžić, 2011, pp. 154-155; Samardžić, 2015, pp. 199-249). Apart from the mentioned objects (I-III) there were numerous smaller premises which were partially preserved and arranged on terraces without direct cohesion. Northern from the second and third object there 
were remains of three buildings (objects IV, V, X, XV) and two tombs (objects VIII, IX). Further to the west from the villa there were discovered basements of a smaller temple (object VII) and remains of a smaller building (object VI). According the remains it could be suggested that a complex of buildings within the luxurious villa had appearance of an oblong square with orientation from south-east towards north-west (AL BiH III 1988, p. 171; Čremošnik, 1960-61, p. 174-182; Čremošnik, 1976, p. 41-58; Busuladžić, 2011, pp. 154-155; Samardžić, 2015, pp. 199-249). Because the villa was located on a plateau which was slightly downcast, a part of the building had irregular position. Buildings were located on the flat plateau of terraces, so their position was influenced by the position and space of these terraces. Besides, in the process of adapting to the position of a terrace, parts of 'U'-building next to the river had slightly higher and stronger foundations. Researched promises of the objects pointed out that they had been mutually connected, so it can be suggested that all remains of the buildings were one complex where the buildings were grouped near smaller and larger open spaces (AL BiH III 1988, p. 171; Čremošnik, 1960-61, pp. 174-182; Čremošnik, 1976, pp. 41-58; Busuladžić, 2011, pp. 154-155; Samardžić, 2015, pp. 199-249).

North-west from the previously described complex of the luxurious villa there was a mount Brijeg, while a terrace plateau was called Dračeva strana. There, to the road towards Dobrićevo, were found numerous Roman ruins. On this location, as well as on the previously described, subsequent building extensions from late antique and medieval period could be seen. The remains of the ruins were shallow, so in most cases only basements were preserved. A slightly convenient picture was on the southern side of Dračeva strana because the terrain was covered by brushwood. On the north-west part of the terrain there were arable land and pasturages, so walls were destroyed during farming of the land. More detailed researches on Dračeva strana started in 1968. On this location the remains of building basements were damaged in the process of clearing land, so in most cases it was impossible to have a clear picture of a complete building, except for certain objects (picture No. 2), (AL BiH III 1988, p. 173; Čremošnik, 1960-61, pp. 174-182; Čremošnik, 1976, pp. 41-58; Busuladžić, 2011, p. 156; Samardžić, 2015, pp. 199-249). From this building complex, only object III was relatively well preserved, while others can be only perceived. Object I on Dračeva strana was partially damaged by 
clearing land because later on in this location a dry wall enclosure was built. Only walls were partially preserved but later on trees had grown on them. Because of that only north-eastern corner of a bigger room was open (object I, premise 2) and a wall against it (objet I, premise 3) which was connected to dry walls. Only parts of object I were found, but according to ceramic fragments and amphora it can be presumed that it served as a larder for everyday groceries in a household (Čremošnik, 1976, pp. 58-65; Busuladžić, 2011, p. 156; Samardžić, 2015, pp. 199-249). Remains of frescoes, ceramics and glass in premises 7 and 8 , as well as remains of estrich in premises 1 and 7 , supported the idea that this was a part of the object II which was used for living. It was thought that, according to nearness and the same orientation, premises 9 and 10 belonged to the object II. Remains of agricultural equipment and slag in the premise 9, as well as fragments of big dishes from the premise 10, pointed out that this was an economic part of the object. In this object there were found remains of one drywall building (AL BiH III 1988, p. 173; Čremošnik, 1976, pp. 58-65; Busuladžić, 2011, p. 156; Samardžić, 2015, pp. 199-249). The object III consisted of three groups of premises which surrounded the complex from north, south and west. Thus they framed irregular shaped courtyard which had entrance to every premise. Remains of walls pointed out that the courtyard was close from eastern side by premises or fence walls. The base of north wall, which connected western and eastern group of premises, was especially well preserved. This wing had two groups of premises. Eastern group had three big premises which, most probably, served for economic purpose, while slightly preserved western group of premises served for living (AL BiH III 1988, p. 173; Čremošnik, 1976, pp. 58-65; Busuladžić, 2011, p. 156; Samardžić, 2015, pp. 199-249). In the southern building wing there were six discovered premises and the examination pointed out that they were used for living (Čremošnik, 1976, pp. 58-65; Samardžić, 2015, pp. 199-249). Object IV consisted of a long premise with stone hearth. The object was located $30-40$ meters northern from object III and it can be presumed that it was an auxiliary building of this household (AL BiH III 1988, p. 173; Čremošnik, 1976, pp. 58-65; Busuladžić, 2011, p. 156; Samardžić, 2015, pp. 199-249). On the basis of different ceramics, objects made of bronze and iron, fragments of glass and money, a villa in Dračeva strana dated back from the end of I or beginning of II century and that it was settled until IV 
century (AL BiH III 1988, p. 173; Čremošnik, 1976, pp. 108-109; Busuladžić, 2011, p. 156; Samardžić, 2015, pp. 199-249).

Traces of Roman presence bid Trebinje Heritage Museum to do detailed archaeological survey during 1972 in Dzivar near Trebinje, and it was stated that the Roman settlement spread over the area of about 3 kilometers. Researchers on this location found remains of bricks, tiles, and certain amount of worked stone (Odavić, 1975, pp. 65-70; Samardžić, 2014, pp. 85-98). Researched locations of Mirina and Lijeska (Bihovo) near Trebinje were very important. Archaeological excavation in Mirine was carried out in 1973 when a Roman building was discovered and explored (villa rustica) (picture No. 3 ). Traces of another villa were discovered near Mirina, on the location of Lijeska, and this fact confirmed that the whole complex was agricultural fundus (Odavić, 1975, pp. 65-70; Busuladžić, 2002, pp. 191-196; Busuladžić, 2011, pp. 153-154; Samardžić, 2015, pp. 261-262).

The villa from the location of Mirina had a square base with seven premises. Dimensions of the object were $26,30 \times 5,75(5,10)$ meters. A premise with dimensions 10, 50x6, 60 meters was considered a separate complex and there was a torcular. This part of the object had two premises divided by a thin wall, thickness 25,30 and $30 \mathrm{~cm}$. Dimensions of the larger premise were 4,07x2,30 meters, and of a smaller one $4,07 \times 1,60 \mathrm{~m}$. The floor was made of smooth surface, slightly pitched toward channel due to easier draining of wine of oil. These premises can be entered through staircase whose two stairs (high $1.60 \mathrm{~m}$ and wide $0.30 \mathrm{~m}$ ) were preserved. The large premise, which included two smaller premises, had entrance door wide $1.45 \mathrm{~m}$ and stone bench (subsellium) which was used for sitting on it. Next to manufacturing premise, from southern side, there was a premise whose dimensions were $11,25 \times 5,75 \mathrm{~m}$. Next to this premise, from western side, there were two smaller premises of approximately same dimensions 3,20 and $(3,30)$ x $3,10 \mathrm{~m}$. The walls were wide $45 \mathrm{~cm}$, while exterior wall was $50 \mathrm{~cm}$ wide. From the northern side there was a premise whose dimensions were $4,55 \mathrm{x}$ $5,10 \mathrm{~m}$. In this premise, as well as in manufacturing premise, remains which most probably indicated a bench (subsellium) were found. The bench was $3.30 \mathrm{~m}$ long and $80 \mathrm{~cm}$ wide and was located next to eastern aslant wall. This premise was connected to aslant wall which was probably the remain of fence. Its width was $5,65 \mathrm{~m}$ and length of so formed space varied from $80 \mathrm{~cm}$ on western to 1,90 m on eastern side (Odavić, 1975, pp. 65-70; Busuladžić, 2002, pp. 
191-196; Busuladžić, 2011, pp. 153-154; Samardžić, 2015, pp. 261-262).

A. Busuladžić suggested that it was an object which can be defined only as villa rustica and that its closest analogies can be found on the area of Epidaur (villa rustica on Sustjepan in Cavtat). What made this object very special was a torcular found in it. Such findings in Bosnia and Herzegovina were very rare and, until now, apart from this, there were only three torcular examples (Mogorjelo, Brotnjo, Višići). Such finding proved a thesis that inhabitants in Herzegovina intensively were involved in wine and olive oil production. Busuladžić stated that although findings and modest equipment can indicate Illyrian ethnicity of the villa's owner, the existence of Roman military fortifications in the neighborhood opened a possibility that an owner can be a veteran or a colonist. Modest dimensions of the object indicated that it was a small individual estate, as in most cases in Bosnia and Herzegovina. Traces of soot were found in premises which indicated that the object was in great fire. It was thought that this object was not directly connected to villas on Panik, but according to few findings in fitted in time framework II-IV century (Odavić, 1975, pp. 65-70; Busuladžić, 2002, pp. 191-196; Busuladžić, 2011, pp. 153-154; Samardžić, 2015, pp. 261-262).

Trebinje Heritage Museum in 1974 organized archaeological excavation on the location of Lijeska, near Mirina, on the place where destroyed bases of Roman building were discovered during construction works of hydro power plants on the Trebišnjica River. During excavation machines elevated a layer of fine floor made of bricks. Two premises were completely researched. It was determined that on one part of the building there were subsequent rearrangements because the wall was of weaker structure. Earth ballast of pyramid shape and stone ball were found on this location. Also, there were found significant number of fine and rough ceramics fragments, thin glass, iron hobnails and the Roman Sestertius with the portrait of Mamaea, wife of Alexander Severus (222-235). $Đ$. Odavić believed that the money could be used for dating of the ancient building. Archeological investigations in the village of Bihovi near Trebinje proved that inhabitants in these Roman settlements lived and labored in III and IV century. Research results showed only fragmented that it was a villa rustica (Paškvalin, 1974 year (No. 67/1-75 from 14. 4. 1975); Odavić, 1975, 
pp. 65-70; Busuladžić, 2002, pp. 192-193 picture 1; Busuladžić, 2011, p. 154; Samardžić, 2015, p. 263).

On the location of Tanoge in Ljubomir, near Trebinje, a part of a huge Roman building was discovered during probationary excavation. On that occasion, a huge premise with $\mathrm{V}$-shaped hypocaust was discovered. Next to this premise there was an apsidal premise where a mosaic with fragments was discovered. Fragments of black, red, grey and yellow Roman ceramics, glass fragments, fibula and bronze needle, destroyed money, fragments of dishes and an amphora, fragments of frescoes, remains of estrich floor and remains of a mosaic were found on the location of Tanoge. It is believed that it was the object which existed from II to IV century (Čremošnik, 1968, pp. 151-152; Busuladžić, 2011, p. 154).

CONCLUSION Extensive archeological research on Panic proved a hypothesis about the existence of Roman settlement on this location. A luxurious city villa was discovered on Crkvina (villa urbana), which is surrounded by a smaller settlement of village villas (villa rustica) on Dračeva strana, Potkućnice and directly to the Trebišnjica River bank, which were purposely and physically connected to the city villa. On the basis of previously mentioned researches, a picture of the estate on Panik was partially formed. Its population was primarily occupied with arable land farming, cattle breeding, viticulture and crafts. In the city villa there were not found traces of workshops which indicated a conclusion that this was a luxurious villa. Remains of millstones, a melting furnace and workshop for brick production on the plateau near the Trebišnjica River belonged to a village villa located on this area. It is assumed that village villas were centers for productive activities for supply of agricultural and other products to the city villa. On the basis of archaeological founds, it can be concluded that the building complex on Dračeva strana was built in the period between the end of I and the beginning of II century, while the city villa on Crkvina was built in the period between III and the beginning of the IV century. One inscription regarding the reconstruction of a bridge and a landmark on the Trebišnjica River pointed out that in the valley of the river in I century there were huge estates of an Italic family Vesii.

Also, it was suggested that researched object on the location of Mirina can be defined only as a villa rustica and that its nearest analogies were located in the area of Epidaur (villa rustica on Sustjepan in Cavtat). The analysis of a torcular proved a hypothesis that 
inhabitants in Herzegovina were practicing the production of wine or olive oil. Modest dimensions of the object indicated that it was, most probably, a small individual estate as in most cases in Bosnia and Herzegovina. The remains of soot in the premises indicated that they suffered a great fire. It was believed that his object was not directly connected to villas on Panik, but on the basis of few evidences it could fit into the same time framework II-IV century.

Damaged bases of Roman buildings were discovered after archeological excavations near Mirine, on the location of Lijeska. During excavation machines elevated a layer of fine floor made of bricks. Two premises were completely researched. Numerous results were found on this location and they could be used for dating of this ancient building. Archeological researches in the village of Bihovi near Trebinje proved that inhabitants in this Roman settlement lived and labored in III and IV century. Research results provided, only fragmented, that this was a villa rustica. On the location of Tanoge in Ljubomir near Trebinje a huge premise with hypocaust and V-shaped channels was discovered. Fragments of black, red, grey and yellow Roman ceramics, glass fragments, fibula and bronze needle, destroyed money, fragments of dishes and an amphora, fragments of frescoes, remains of estrich floor and remains of a mosaic were found on this location. It was believed that this object existed from II to IV century.

Next to this premise there was an apsidal premise where a mosaic with fragments was discovered. Fragments of black, red, grey and yellow Roman ceramics, glass fragments, fibula and bronze needle, destroyed money, fragments of dishes and an amphora, fragments of frescoes, remains of estrich floor and remains of a mosaic were found on the location of Tanoge.

It could be concluded that centers of great estates of families of Italic origin were formed relatively early in this area as it was case in Panik. A luxuriously furnished city villa was discovered on Crkvina (villa urbana), surrounded by a smaller settlement of village villas (villa rustica) on Drečeva strana, Potkućnice and very close to the bank of the Trebišnjica River which were purposely and spatially connected to the city villa. On the basis of the researches mentioned above, a picture of the estate in Panik (Bileća) was formed to a certain extent. Also, locations with rustical villas (Mirine, Lijeska, Tanoge) were discovered southern from Bileća, on the area of Trebinje municipality, and these locations witnessed intensive agricultural production and livestock breeding. Economy 
of this region was based on livestock breeding and farming the larger estates by domestic inhabitants (land farming, livestock breeding, viticulture and crafts), on large estates of Roman colonists with villas as centers of economy. On this way village villas were centers of productive activities for providing city villas with agricultural and other products. 


\section{ABBREVIATIONS}

AL BiH Arheološki leksikon Bosne i Hercegovine, Sarajevo.

AE L'Annee epigraphique. Revue des publications epigraphiques relatives a l'Antiquite romaine, Paris.

ANU BiH Akademija nauka i umjetnosti Bosne i Hercegovine, Sarajevo.

GZM BiH Glasnik Zemaljskog muzeja u Bosni i Hercegovini, Sarajevo.

CBI Centar za balkanološka ispitivanja, Sarajevo.

CIL Corpus Inscriptiones Latinarum, Berolini.

ILJug Šašel, A. et J. (1963). Inscriptiones Latinae quae in Iugoslavia Inter annos MCMXL et MCMLX repertae et editae sunt. Ljubljana: Situla, 5, Narodni muzej Slovenije.

Šašel, A. et J. (1978). Inscriptiones Latinae quae in Iugoslavia Inter annos MCMLX et MCMLXX repertae et editae sunt. Ljubljana: Situla 19, Narodni muzej Slovenije.

VAMZ Vjesnik arheološkog muzeja u Zagrebu, Zagreb.

SOURCES Arheološki leksikon Bosne i Hercegovine, III, Mape 1-4, Zemaljski muzej, Sarajevo

Itinerarium Antonini, (1848). Itinerarium Antonini Augusti et Hierosolymitanum. Berlin: ed. G. Parthey et M. Pinder.

L'Annee epigraphique, (1977). Revue des publications epigraphiques relatives a l'Antiquite romaine. Paris.

Müller, C. (1916). Itineraria Romana, Römische Reisenwege an der Han Der Tabula Peutingeriana. Stuttgart: Strecker und Schröder in Stuttgart.

Kolbt, A. / Walser, G. / Jansen, U. (2012). Miliaria Imperii Romani, Illyricum et provinciae Evropae Graecae. Berlin: De Gruyter.

Corpus Inscriptionum Latinarum, (1873). Consilio et auctoritate Academiae litterarum regiae. Berolini: Borussicae editum, ed. Th. Mommsen, Voll. III.

Šašel, A. et J. (1963). Inscriptiones Latinae quae in Iugoslavia Inter annos MCMXL et MCMLX repertae et editae sunt. Ljubljana: Situla 5, Narodni muzej Slovenije.

Šašel, A. et J. (1978). Inscriptiones Latinae quae in Iugoslavia Inter annos MCMLX et MCMLXX repertae et editae sunt. Ljubljana: Situla 19, Narodni muzej Slovenije.

REFERENCES Alföldy, G. (1969). Die Personnennamen in der romischen Provinz Dalmatia. Heidelberg: Carl Winter UNIVERSITATSVERLAG. 
Bojanovski, I. (1962). „Arheološki spomenici u dolini Trebišnjice” Naše starine VIII, Sarajevo,11-13.

Bojanovski, I. (1964). „Bilješke iz arheologije I”. GZM u Sarajevu, ns, IX,193-198.

Bojanovski, I. (1973). „Rimska cesta Narona - Leusinijum kao primjer saobraćajnog kontinuiteta". Godišnjak ANUBiH X, CBI knj. 8, Sarajevo,137-187.

Bojanovski, I. (1976). „Gatačko polje u antici”. Tribunia, 2, 17-44.

Bojanovski, I. (1977). „Rimski natpisi iz doline Trebišnjice”. Tribunia, 3, 67-98.

Bojanovski, I. (1983). „Trebinje - rimski Asamo (Asamum) sa kratkim osvrtom na ager kolonije Epidaura". Tribunia 7, 7-36.

Bojanovski, I. (1988). Bosna i Hercegovina u antičko doba. Sarajevo: ANUBIH Djela knj. LXVI, CBI knj. 6.

Busuladžić, A. (2002). „Villa rustica u Bihovu kraj Trebinja”. VAMZ, 3.s., XXXV, 191-196.

Busuladžić, A. (2011). Rimske vile u Bosni i Hercegovini. Sarajevo: Zemaljski muzej Bosne i Hercegovine.

Mielsch, H. (1987). Die römische Villa - Architekture und Lebensform. Minchen.

Paškvalin, V. (1976). „Antički torkular u Bihovu kod Trebinja”. GZMu Sarajevu XXIX, 289-293.

Pecival, J. (1976). The Roman Villa. London.

Самарџић, Г. (2015). Исйочна Хериеїовина у римско gоба. Косовска Митровица: Филозофски факултет у Приштини.

Smith, J. T. (2006). Roman Villas: A Study in Social Structure. London and New York.

Sergejevski, D. (1962a). „Rimska cesta od Epidauruma do Anderbe”. GZM u Sarajevu, XVII, 73-104.

Sergejevski, D. (1962ס). „Rimska cesta Narona-Leusinium, GZM u Sarajevu, XVII, 111-113.

Sergejevski, D. (1964). „Borne frontiere romaine de Kosijerevo”. Archaelogica Iugoslavica, V, 93-95.

Fiala, F. (1893). „Prilozi rimskoj arheologiji Hercegovine”. GZM u Bosni i Hercegovini, V, 511-532.

Čremošnik, I. (1968). „Tanoge u Ljubomiru kod Trebinja - rimsko naselje”. Arheološki pregled, 10, Beograd, 151-152.

Čremošnik, I. (1976). „Rimsko naselje na Paniku kod Bileće”. GZM u Sarajevu XXIX, 41-132. 
Truhelka, Ć. (1892). „Prilozi rimskoj arheologiji Bosne i Hercegovine”. GZMu Bosni i Hercegovini, IV, 340-365.

Thomas, E. (1980). Villa setlements, in The Archaeology of Roman Pannonia. Budapest: ed. A. Lengyel and T. B. Radan.

Шкриванић, Г. (1975). „Југославенске земље на Појтингеровој табли”. Monumenta captogpaphica Jugoslaviae I, Beograd, 50-51.

\section{APPENDIX}

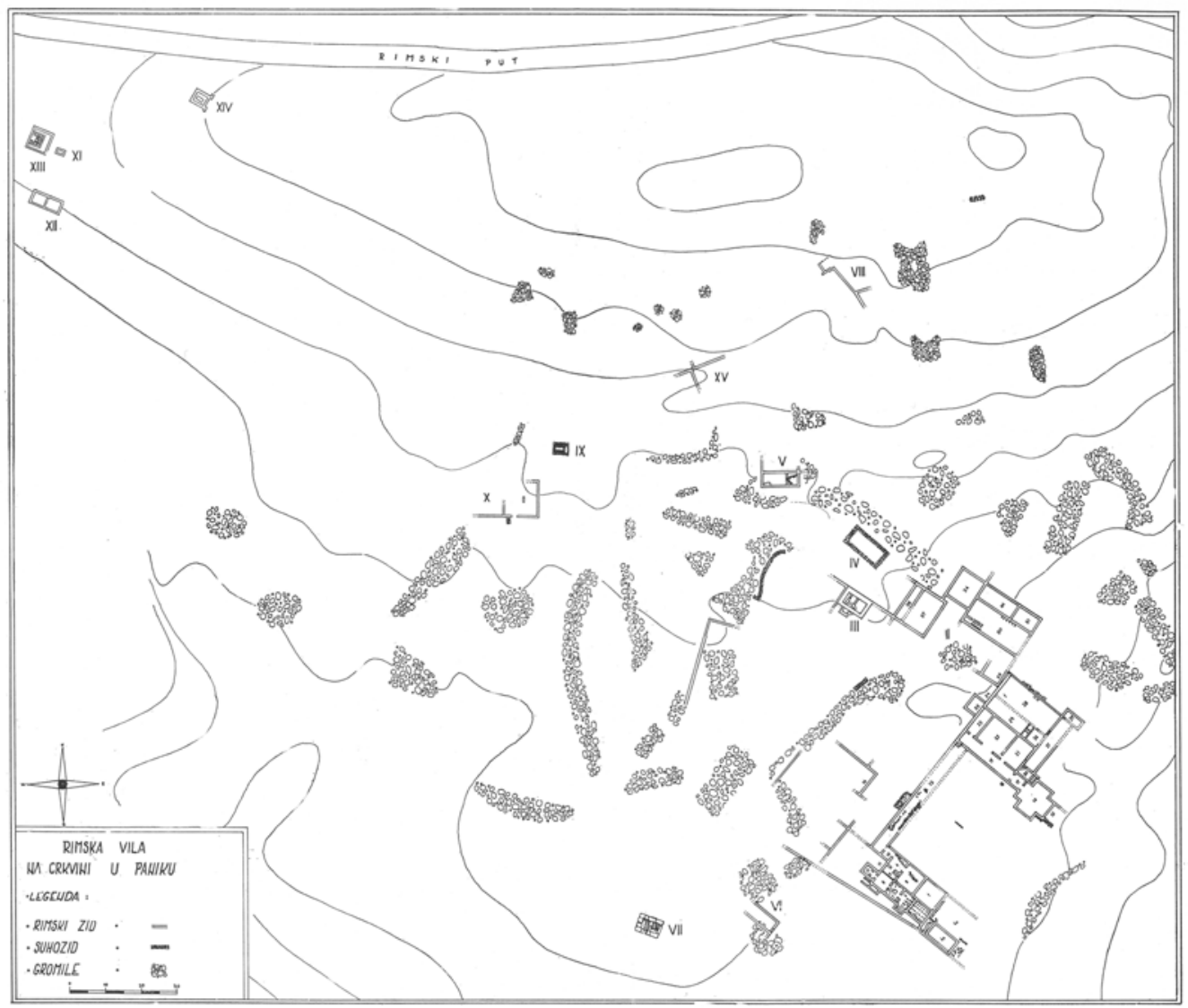

Picture 1: 1: VilLA on CRKVINA - PANIK (ČREMOŠNIK, 1976). 


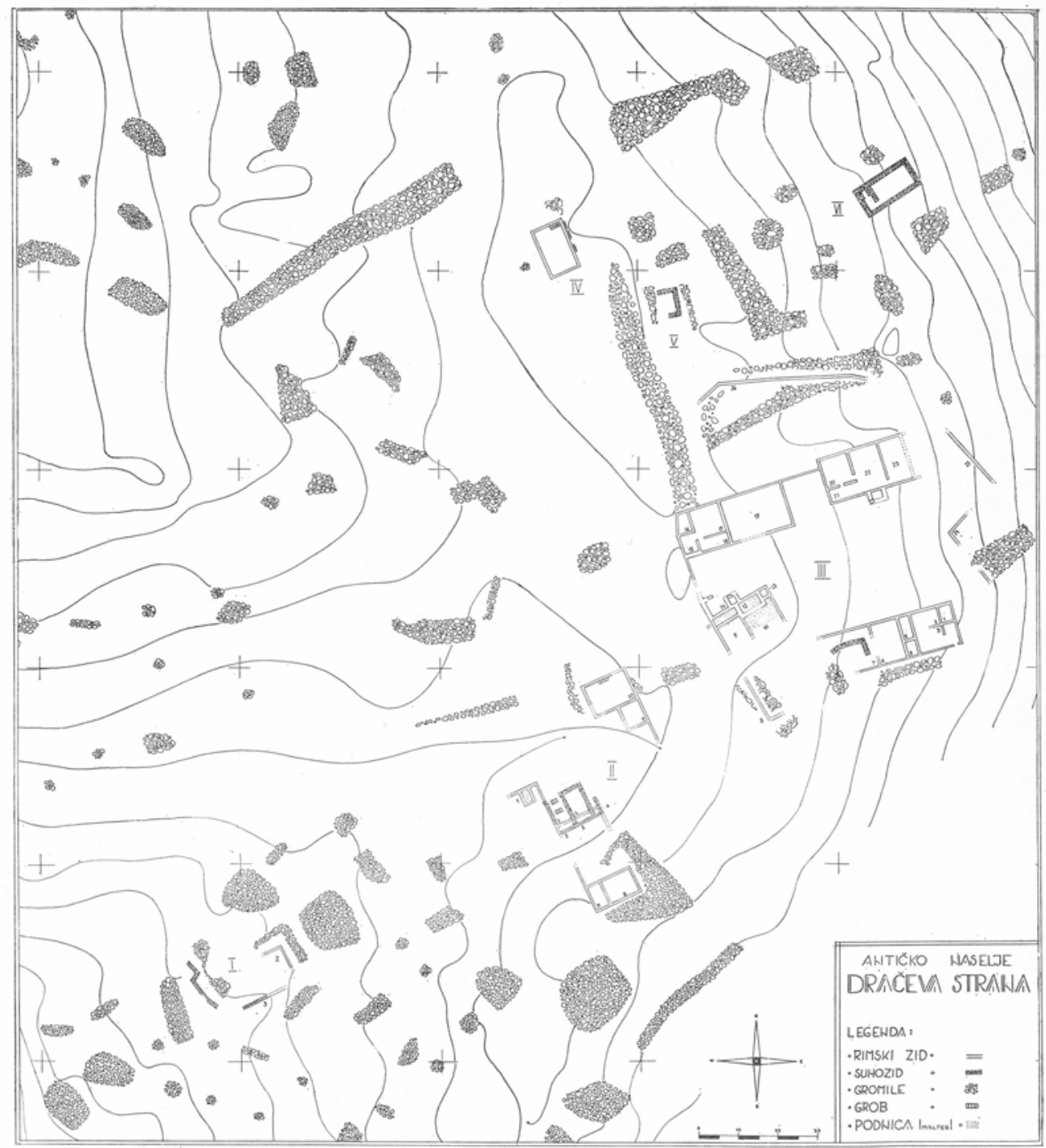

Picture 2: VilLA ON DRAČEVA STRANA - PANIK (ČREMoŠNiK, 1976). 


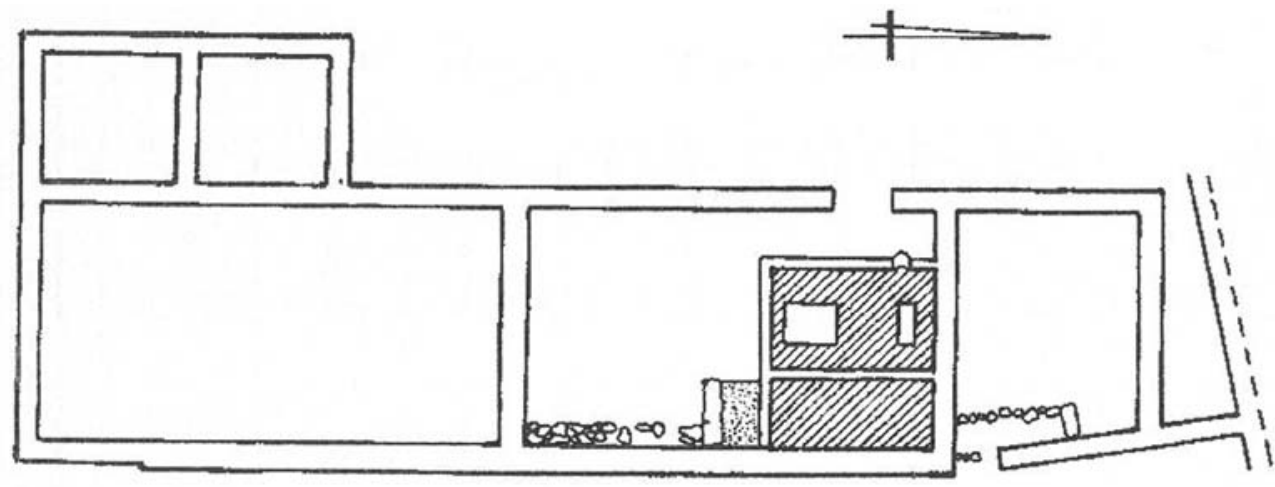

トレトトト

Picture 3: Villa RUSTica on the Location of MiRine in BiHovo NEAR TREBINJE (BuSULADŽÍć, 2002, P. 193). 
ГЛИГОР М. САМАРЏИТ

УНИВЕРЗИТЕТ У ПРИШТИНИ С ПРИВРЕМЕНИМ СЕДИШТЕМ

У КОСОВСКОЈ МИТРОВИЦИ, ФИЛОЗОФСКИ ФАКУЛТЕТ

КАТЕДРА ЗА ИСТОРИЈУ

РЕЗИМЕ

БИЉЕШКЕ О РИМСКИМ ВИЛАМА СА ЈУГА ПРОВИНЦИЈЕ ДАЛМАЦИЈЕ (НЕКОЛИКА ПРИМЈЕРА СА ПОДРУЧЈА ИСТОЧНЕ ХЕРЦЕГОВИНЕ)

У раду су презентовани подаци о римским вилама у долини ријеке Требишњице - источна Херцеговина (југ провинције Далмације). Основу за успјешно истраживање римских вила на југу провинције Далмације представља писана изворна грађа и материјални остаци на терену (епиграфски споменици, остаци зграда, насеља, и путева, фрагменти цигле, цријепа, обрађеног камена, римске керамике, фрагменти стакла, посуда и амфора, фрагменти фресака, остаци мозаика, торкулара, новац и др.). Археолошки налази указују да се континуитет насељавања овог подручја може пратити од предисторијског до најновијег доба. Подручје које се у овом раду истражује углавном гравитира око ријеке Требишњице. Ријеч је о простору са врло повољним климатским условима који погодују развоју пољопривреде и сточарства. То је доприносило да ово подручје буде гушће насељено и у античко доба. Овом приликом у раду смо презентовали налазе из римског доба који су откривени на локалитетима Црквина, Драчева страна, Поткућнице (Паник-Билећа), Мирине, Лијеска, Таноге (Требиње). Откривена је луксузно опремљена градска вила (villa urbana) на Црквини, коју окружује мање насеље сеоских вила (villa rustica) на Драчевој страни, Поткућницама и уз саму обалу ријеке Требишњице, намјенски и просторно везаних за градску вилу. Такође, јужно од Билеће у Требињској општини откривени су локалитети са рустикалним вилама (Мирине, Лијеска, Таноге,) који свједоче о интезивној земљорадничкој и сточарској производњи.

Кључне речи: римске виле, Паник, Црквина, Драчева страна, Поткућнице, Мирине, Лијеска, Бихово, Таноге, Љубомир, источна Херцеговина, Далмација. 